\title{
Reclassification of equine isolates previously reported as Actinobacillus equuli, variants of $A$. equuli, Actinobacillus suis or Bisgaard taxon 11 and proposal of $A$. equuli subsp. equuli subsp. nov. and $A$. equuli subsp. haemolyticus subsp. nov.
}

Department of Veterinary Microbiology, The Royal Veterinary and

Agricultural University, 4 Stigbøjlen, DK-1870

Frederiksberg C, Denmark

\author{
Henrik Christensen, Magne Bisgaard and John Elmerdahl Olsen
}

Author for correspondence: Henrik Christensen. Tel: +45 35282783. Fax: +4535282757. e-mail: hech@kvl.dk
Keywords: Actinobacillus equuli, Bisgaard taxon 11, DNA hybridization, 16S rRNA, taxonomy

\section{INTRODUCTION}

Contradictory statements were given on the genus Actinobacillus in the first edition of Bergey's Manual of Systematic Bacteriology. Five species were listed as members of the genus by Phillips (1984), while Mannheim (1984) suggested Actinobacillus sensu stricto to include seven species, excluding Actinobacillus actinomycetemcomitans included by Phillips. Based upon DNA homology studies, Mutters et al. (1989) suggested that the genus should be limited to the following

A full DNA-binding matrix is available as supplementary material in IJSEM Online (http://ijs.sgmjournals.org/).

The GenBank/EMBL/DDBJ accession numbers for the 16S rRNA gene sequences of $A$. equuli and Bisgaard taxon 11 strains determined in this study are AF247713-AF247716, AF247718 and AF247720-AF247721, as shown in Fig. 1. species: Actinobacillus lignieresii, Actinobacillus equuli, Actinobacillus capsulatus, Actinobacillus suis, Actinobacillus ureae, Actinobacillus hominis, Actinobacillus pleuropneumoniae and Bisgaard's taxa 5, 9 and 11.

A 16S rRNA sequence comparison by Dewhirst et al. (1993) grouped the true actinobacilli in cluster 4A and confirmed that Actinobacillus sensu stricto should be confined to those taxa proposed by Mutters et al. (1989) with the exception of A. capsulatus and Bisgaard's taxa 5 and 9. In the analysis, Bisgaard's taxa 8 and 9 were contained in cluster $4 \mathrm{~B}$, closely related to the genus Actinobacillus sensu stricto. Three novel species of Actinobacillus from pigs were reported by Møller et al. (1996), of which Actinobacillus minor was shown to belong to Dewhirst cluster 4B together with Bisgaard's taxa 8 and 9, while Actinobacillus porcinus and Actinobacillus indolicus branched more deeply. Five additional species of Actinobacillus, Actino- 
bacillus delphinicola (Foster et al., 1996), Actinobacillus rossii (Sneath \& Stevens, 1990), Actinobacillus scotiae (Foster et al., 1998), Actinobacillus seminis (Sneath \& Stevens, 1990) and Actinobacillus succinogenes (Guettler et al., 1999), have been reported, although $16 \mathrm{~S}$ rRNA sequence comparison showed that they should be classified outside the genus Actinobacillus sensu stricto as defined by DNA-DNA hybridization.

Taxon 9 has recently been split into the two taxa, Actinobacillus arthritidis and Actinobacillus genomospecies 2, while strains of $A$. lignieresii isolated from horses have been proposed as Actinobacillus genomospecies 1 (Christensen et al., 2002). In subsequent discussions in the present paper, genuine actinobacilli are defined according to Mutters et al. (1989) to include $A$. arthritidis, $A$. equuli, A. lignieresii, $A$. pleuropneumoniae, A. suis, A. ureae, Bisgaard taxa 8 and 11 and Actinobacillus genomospecies 1 and 2, excluding A. capsulatus, A. minor and Bisgaard taxon 5.

Among the true species of Actinobacillus, A. equuli, A. arthritidis, Bisgaard taxon 11 and Actinobacillus genomospecies 1 and 2 have so far been reported from horses (Bisgaard, 1993). These organisms may cause disease in horses and may be found in infected wounds of humans bitten by horses (Ashhurst-Smith et al., 1998; Dibb et al., 1981; Peel et al., 1991). Recent studies, however, have emphasized the need for careful examination of equine isolates previously identified as A. equuli (Blackall et al., 1997). These studies also showed that some isolates could not be assigned to any currently recognized species or taxa.

The diversity of $A$. equuli was reported by Bisgaard (1993), who classified trehalose-negative strains as taxon 9. Since production of acid from $(+) \mathrm{L}$-arabinose was shown to be of taxonomic significance in the reclassification of [Haemophilus] avium into three novel species (Mutters et al., 1985), Bisgaard (1993) also drew attention to the existence of $(+) \mathrm{L}$-arabinosepositive strains of $A$. equuli, the taxonomy of which remains to be investigated. The diversity of $A$. equuli was subsequently confirmed by ribotyping (Blackall et al., 1998; Sternberg \& Brändström, 1999). (+)LArabinose-positive strains clustered separately, joining the $A$. equuli cluster at approximately $50 \%$ similarity, while taxon 9 branched more deeply (Blackall et al., 1998).

Equine strains of bacteria described as A. suis or haemolytic variants of $A$. equuli were classified as taxon 11 with four biovars, of which only three biovars have been kept (Bisgaard et al., 1984). Further investigations have confirmed the existence of taxon 11, since haemolytic $A$. lignieresii-like strains isolated from horses had a PAGE profile different from that of the bovine reference strain (Jang et al., 1987; Samitz \& Biberstein, 1991). Lower airway inflammation of horses was significantly associated with taxon 11-like bacteria and A. lignieresii (Ward et al., 1998).
The uncertain taxonomy of the above-mentioned equine taxa represents a diagnostic problem and prevents progress on studies of the virulence and epidemiology of these organisms. In the present investigation, we decided to undertake a study involving 16S rRNA sequencing of selected strains representing equine taxa of uncertain taxonomy and to compare the sequences obtained with those published previously, in order to clarify the phylogeny of these organisms further. In addition, DNA-DNA hybridizations were carried out to classify organisms previously reported as equine $A$. suis, haemolytic variants of $A$. equuli or Bisgaard taxon 11.

\section{METHODS}

Bacterial strains and phenotypic characterization. Selection of strains (Table 1) was based on previous investigations (Bisgaard et al., 1984; Blackall et al., 1997, 1998; Carman \& Hodges, 1982; Mráz et al., 1968; Peel et al., 1991) and strains retained in our laboratory. Phenotypic characterization was performed as reported previously (Bisgaard et al., 1991).

Sequencing of $16 \mathrm{~S}$ rRNA genes. Bacteria were cultured overnight in brain/heart infusion broth (Difco) at $37^{\circ} \mathrm{C}$. Cells from $1 \mathrm{ml}$ culture were harvested by centrifugation and DNA extraction was performed according to Leisner et al. (1999). PCR amplification was performed as described by Vogel et al. (1997). Oligonucleotides for both PCR amplification and sequencing were synthesized according to sequences and 16S rRNA positions given by Dewhirst et al. (1989) and Paster \& Dewhirst (1988). PCR-amplified fragments were purified and cycle-sequenced as reported by Christensen et al. (2002).

Analysis of sequence data. Searches for $16 \mathrm{~S}$ rRNA sequences were performed by FASTA and BLAST in GenBank by use of the Wisconsin Sequence Analysis package (Genetics Computer Group, Madison, WI, USA). Sequences were aligned manually to the Escherichia coli $\operatorname{rrs} B$ sequence and to the consensus sequence (Lane, 1991). The region corresponding to $E$. coli positions $28-1480$ could be aligned and 1378 nucleotides (87 distinct data patterns analysed) were left after removal of ambiguous positions. Maximum-likelihood analysis was performed by fastDNAmL including bootstrap analysis (Felsenstein, 1981; Olsen et al., 1994) run on an HP9000/819 computer (UNI-C, Lyngby, Denmark). Parsimony and neighbour-joining analysis were performed by PHYLIP (Felsenstein, 1995).

DNA-DNA hybridization. DNA similarities were determined according to the micro-well method (Christensen et al., 2000) with the modifications that only DNA of high concentration $\left(>150 \mu \mathrm{g} \mathrm{ml}^{-1}\right)$ was used and coated plates were hybridized within a few days. To eliminate 'edge' effects during binding of DNA to wells and hybridization, these steps were carried out in a small, closed, humidified chamber in addition to sealing wells with tape, as reported previously (Christensen et al., 2000). Hybridizations were repeated if the difference between DNA binding values obtained by reversal of strains for binding and hybridization was more than $20 \%$. A dendrogram was generated by Fitch-Margoliash analysis with the 'contemporary tips' option (KITSCH) as provided in the PHYLIP package. 
Table 1. Strains of equine taxa investigated

\begin{tabular}{|c|c|c|c|c|}
\hline Strain & Taxon & Source & Country of isolation & Reference(s) \\
\hline NCTC $4189^{\mathrm{T}}$ & A. lignieresii & Cow & $\mathrm{UK}$ & \\
\hline T $355 / 87$ & Bisgaard 11 bv. 1 & Horse bite & Australia & Peel et al. (1991) \\
\hline F 92 & Bisgaard 11 bv. 1 & Horse & Denmark & Bisgaard et al. (1984) \\
\hline Ac 7 & Bisgaard 11 bv. 1 & Horse & Zimbabwe & Mohan et al. (1997) \\
\hline $\begin{aligned} \mathrm{F} 154^{\mathrm{T}}( & =\text { Carman } 8-11272^{\mathrm{T}}=\mathrm{CCUG} \\
19799^{\mathrm{T}} & \left.=\text { NCTC } 13195^{\mathrm{T}}\right)\end{aligned}$ & Bisgaard 11 bv. 2 & Horse & New Zealand & $\begin{array}{l}\text { Carman \& Hodges (1982), } \\
\text { Bisgaard et al. (1984) }\end{array}$ \\
\hline F $490(=$ CCM 5587) & Bisgaard 11 bv. 2 & Horse & Czech Republic & $\begin{array}{l}\text { Mráz et al. (1968), } \\
\text { Bisgaard et al. (1984) }\end{array}$ \\
\hline F 119 & Bisgaard 11 bv. 3 & Horse & Denmark & Bisgaard et al. (1984) \\
\hline $\operatorname{NCTC} 8529^{\mathrm{T}}\left(=\mathrm{F} 102^{\mathrm{T}}=\right.$ ATCC $\left.19392^{\mathrm{T}}\right)$ & A. equuli & Horse & UK & \\
\hline I $5445 / 4$ & A. equuli & Horse & Australia & Blackall et al. $(1997,1998)$ \\
\hline
\end{tabular}

bv., Biovar.

\section{RESULTS AND DISCUSSION}

\section{Phenotypic characterization}

The phenotypic characterization of strains of Bisgaard taxon 11 and $(+) \mathrm{L}$-arabinose-positive $A$. equuli summarizes results published previously (Bisgaard et al., 1984; Blackall et al., 1997; Christensen et al., 2002). All equine strains of $A$. equuli, $(+) \mathrm{L}$-arabinose-positive variants of $A$. equuli, Bisgaard taxon 11, A. arthritidis, Actinobacillus genomospecies 2 and the type strain of A. lignieresii were positive in Hugh-Leifson medium with (+)D-glucose (fermentative), porphyrin test, nitrate reduction, urease, alanine aminopeptidase, phosphatase and ONPG and produced acid from $(-) \mathrm{D}-$ ribose, $(-) \mathrm{D}$-fructose, $(+) \mathrm{D}$-glucose, $(+) \mathrm{D}$-mannose, $(+) \mathrm{D}$-xylose, maltose, dextrin and sucrose. The bacteria were Gram-negative. Negative results were obtained in the following tests: motility at 22 and $37^{\circ} \mathrm{C}$, symbiotic growth, Simmons citrate, mucate-acid, malonate-base, $\mathrm{H}_{2} \mathrm{~S}$ /tri-sugar iron (TSI), growth in the presence of $\mathrm{KCN}$, methyl red and Voges-Proskauer tests at $37^{\circ} \mathrm{C}$, production of gas from nitrate, arginine dihydrolase, lysine decarboxylase, ornithine decarboxylase, phenylalanine deaminase, indole production, gelatinase, hydrolysis of Tweens 20 and 80, pigment formation, $\alpha$-fucosidase (o-nitrophenyl $\alpha$-Lfucopyranoside; ONPF), $\alpha$-glucuronidase ( $p$-nitrophenyl $\beta$-D-glucopyranosiduronic acid; PGUA), $\alpha$ mannosidase and formation of acid from $m$-erythritol, adonitol, (+)D-arabitol, xylitol, $(-) \mathrm{L}-\mathrm{xylose}$, dulcitol, $m$-inositol, $(+) \mathrm{D}-$ fucose, $(+) \mathrm{L}$-rhamnose, $(-) \mathrm{L}$-sorbose, $(+) \mathrm{D}$-melezitose, $(+) \mathrm{D}-\mathrm{glyc} \operatorname{cogen}$, inulin, $(+) \mathrm{D}-$ turanose and $\beta-N-\mathrm{CH}_{3}-$ glucosamid. Formation of gas from $(+)$ D-glucose was not observed.

Results for the 25 characters for which the strains varied are given in Table 2. Only differences in oxidase and production of acid from $(+) \mathrm{L}$-arabinose separate strain I 5445/4 from the type strain of $A$. equuli. This group can be separated from the type strain of $A$. lignieresii by differences in production of acid from $(-) \mathrm{L}$-fucose, $(+) \mathrm{D}$-melibiose, trehalose and raffinose, $\alpha$-galactosidase, $o$-nitrophenyl $\beta$-D-xylanopyranoside (ONPX) and $p$-nitrophenyl $\alpha$-D-glucopyranoside (PNPG). The presence of $\beta$-haemolysis separates taxon 11 from the other equine groups. With the exception of F 119 (biovar 3), this group produces acid from glycosides. From a phenotypic point of view, biovar 3 of taxon 11 appears as a (-)D-mannitol-negative strain of A. equuli. Within biovars 1 and 2 of taxon 11, variations are observed in formation of acid from $(+)$ L-arabinose, $(-)$ D-mannitol, $(-)$ D-sorbitol and aesculin and in the PNPG test. Differences in $(-) \mathrm{D}$ mannitol and PNPG separate biovars 1 and 2 of taxon 11 .

\section{S rRNA sequence comparison}

16S rRNA sequences were obtained for seven strains of equine actinobacilli. The sequences were identical for strains CCUG $19799^{\mathrm{T}}$ (GenBank accession no. M75067) and $F$ 154 (GenBank accession no. AF247716; this investigation). These strains represent identical depositions under different strain designations. It should be noted that strain CCUG $19799^{\mathrm{T}}$ belongs to taxon 11 . However, this strain was misnamed $A$. capsulatus when the sequence was deposited under accession number M75067. The type strain of [Haemophilus] parahaemolyticus showed only $0 \cdot 1 \%$ difference in 16S rRNA sequence from A. equuli, but was excluded from the analysis, since it has recently been shown not to be the sequence of the strain reported (Hedegaard et al., 2001).

The phylogenetic tree shown in Fig. 1 is based on the seven sequences determined in the present study and published sequences of genuine actinobacilli, with $A$. minor included as an outgroup. A phylogenetic analysis performed by inclusion of representative taxa of the remaining part of the family Pasteurellaceae (Pohl 1981) showed that the actinobacilli included in Fig. 1 formed a monophyletic unit (data not shown). The phylogeny was poorly resolved and only the group with $A$. lignieresii, the type species of the genus, $A$. 
Table 2. Phenotypic characters for which the selected equine actinobacilli investigated were variable

Strains are identified as: 1 , NCTC $8529^{\mathrm{T}} ; 2$, I 5445/4; 3, F 92; 4, T 355/87; 5, Ac 7; 6, F 154 ; 7, F 490; 8, F 119; 9 ,

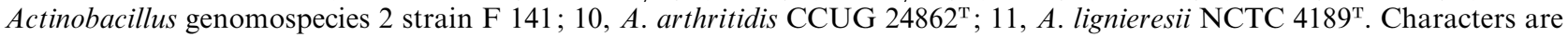
scored as: + , positive within $1-2$ days; $(+)$, delayed positive ( $\geqslant 3$ days); - , negative after 14 days; w, weakly positive. NPG, $p$-Nitrophenyl $\beta$-D-glucopyranoside; ONPX, $o$-nitrophenyl $\beta$-D-xylanopyranoside; PNPG, $p$-nitrophenyl $\alpha$-D-glucopyranoside; TMPD, tetramethyl $p$-phenylenediamine.

\begin{tabular}{|c|c|c|c|c|c|c|c|c|c|c|c|}
\hline \multirow[t]{3}{*}{ Character } & \multicolumn{2}{|c|}{ A. equuli subsp. equuli } & \multicolumn{6}{|c|}{ A. equuli subsp. haemolyticus } & \multirow[b]{3}{*}{9} & \multirow[b]{3}{*}{10} & \multirow[b]{3}{*}{11} \\
\hline & \multirow[b]{2}{*}{1} & \multirow[b]{2}{*}{2} & \multicolumn{3}{|c|}{ Biovar 1} & \multicolumn{2}{|c|}{ Biovar 2} & \multirow{2}{*}{$\frac{\text { Biovar } 3}{8}$} & & & \\
\hline & & & 3 & 4 & 5 & 6 & 7 & & & & \\
\hline Catalase & + & $\mathrm{W}$ & + & $\mathrm{w}$ & + & + & w & W & + & + & + \\
\hline Oxidase, TMPD & + & - & + & + & + & + & + & + & + & + & + \\
\hline$\beta$-Haemolysis & - & - & $\mathrm{w}$ & $\mathrm{w}$ & $\mathrm{w}$ & $\mathrm{w}$ & + & w & - & - & - \\
\hline Growth on MacConkey agar & - & - & - & - & - & - & - & $\mathrm{W}$ & $\mathrm{w}$ & - & - \\
\hline \multicolumn{12}{|l|}{ Production of acid from: } \\
\hline Glycerol & $(+)$ & $(+)$ & $(+)$ & + & + & $(+)$ & $(+)$ & $(+)$ & $(+)$ & $(+)$ & $\mathrm{W}$ \\
\hline$(+)$ L-Arabinose & - & + & - & - & - & - & + & - & - & - & - \\
\hline$(-) \mathrm{D}$-Arabinose & - & - & - & - & - & - & - & - & $(+)$ & - & - \\
\hline$(-)$ D-Mannitol & + & + & - & - & - & + & + & - & + & + & + \\
\hline$(-) \mathrm{D}-$ Sorbitol & - & - & - & - & - & + & - & - & - & + & - \\
\hline$(-)$ L-Fucose & - & - & - & - & - & - & - & - & + & - & + \\
\hline$(+) \mathrm{D}-$ Galactose & + & + & + & + & + & + & + & + & + & $(+)$ & + \\
\hline Cellobiose & - & - & + & + & + & + & + & - & - & - & - \\
\hline$\beta$-Glucosidase (NPG) & - & - & + & + & + & + & + & - & - & - & - \\
\hline \multicolumn{12}{|l|}{ Production of acid from: } \\
\hline Lactose & + & + & + & + & + & + & + & + & + & + & $\mathrm{W}$ \\
\hline$(+)$ D-Melibiose & + & + & + & + & + & + & + & + & $(+)$ & $(+)$ & - \\
\hline Trehalose & + & + & + & + & + & + & + & + & - & - & - \\
\hline Raffinose & + & + & + & + & + & + & + & + & $(+)$ & + & - \\
\hline Aesculin & - & - & + & + & - & - & - & - & - & - & - \\
\hline Amygdalin & - & - & $(+)$ & $(+)$ & $(+)$ & $(+)$ & $(+)$ & - & - & - & - \\
\hline Arbutin & - & - & + & + & + & + & + & - & - & - & - \\
\hline Gentiobiose & - & - & + & + & + & + & + & - & - & - & - \\
\hline Salicin & - & - & + & + & + & + & + & - & - & - & - \\
\hline$\alpha$-Galactosidase & + & + & + & + & + & + & + & + & + & + & - \\
\hline$\alpha$-Glucosidase (PNPG) & + & + & + & + & + & - & - & + & - & - & - \\
\hline$\beta$-Xylosidase (ONPX) & + & + & - & $\mathrm{w}$ & + & + & + & + & - & - & - \\
\hline
\end{tabular}

pleuropneumoniae and, distantly related to these species, taxon 8 was consistent with all three phylogenetic methods. The lowest similarity within this group was $97 \%$, between the strain of Bisgaard taxon 8 and the type strain of $A$. pleuropneumoniae. A second group was formed by the type strain of $A$. ureae, the type strain of A. arthritidis, Actinobacillus genomospecies 2 and one strain of taxon 11, but was only supported by maximum-likelihood analysis. The lowest similarity within this group was $98 \%$, observed between $A$. ureae and Actinobacillus genomospecies 2. The remaining strains, representing Bisgaard taxon 11, A. equuli, $A$. suis and $A$. hominis, did not form monophyletic groups but instead gave a comb-like topology without consistency compared with results obtained by neighbourjoining and parsimony analysis. A similar topology was recently reported for some taxa of Mannheimia
(Blackall et al., 2001). The reason for the poorly resolved phylogeny is probably that there is too little sequence variation between the taxa, with the result that random variation gives noise in relation to the phylogenetic signal, since the highest variation was only $1 \cdot 3 \%$, observed between strains F 92 and F 119 and the type strain of $A$. hominis. A high similarity of $99.9 \%$ was found between strain I $5445 / 4$, reported as (+)L-arabinose-positive $A$. equuli, and the type strain of $A$. equuli. The lowest similarity between the strains of Bisgaard taxon 11 was between strain Ac 7 and the five other strains, with 98-99\% similarity, compared with $98 \cdot 7-99 \cdot 7 \%$ similarity between these five strains.

The lowest similarity between $A$. lignieresii, A. hominis, $A$. arthritidis, A. pleuropneumoniae, A. equuli, $A$. hominis, A. suis, Bisgaard taxa 8 and 11 and Actino- 


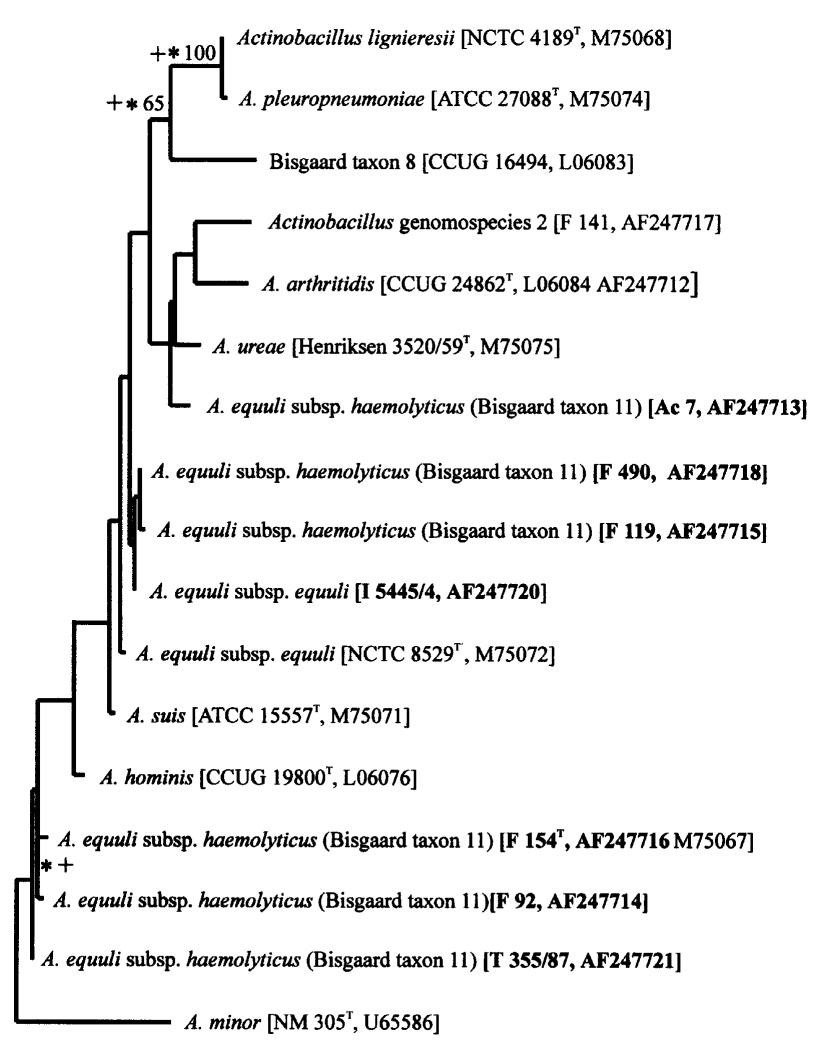

0.01 evolutionary distance

Fig. 1. Phylogenetic relationships between selected taxa associated with horses and published sequences of genuine actinobacilli based on maximum-likelihood analysis of 16S rRNA sequences. The significance for specific nodes obtained in bootstrap analysis $(n=100)$ is indicated for values greater than $50 \%$. Nodes supported in phylogenetic trees obtained by neighbour-joining and parsimony methods are respectively indicated by + and *. Strains sequenced in the present study are in bold. Strain and GenBank accession numbers are given in brackets.

bacillus genomospecies 1 and 2, considered as Actinobacillus sensu stricto in the present study, was $95.6 \%$, found between the strain of Bisgaard taxon 8 and strain $\mathrm{T} 355 / 87$ of taxon 11 . However, this range covered a continuum of closely related taxa. Comparison of $16 \mathrm{~S}$ rRNA sequences showed that $A$. actinomycetemcomitans, A. capsulatus, A. delphinicola, A. indolicus, A. minor, Actinobacillus muris, A. porcinus, $A$. scotiae, $A$. seminis and $A$. succinogenes were distantly related to $A$. lignieresii, $A$. pleuropneumoniae, A. equuli, A. hominis, A. suis, A. arthritidis, Bisgaard taxa 8 and 11 and Actinobacillus genomospecies 1 and 2. The highest similarities observed between these two groups of taxa were 95.4 (A. suis) to $96.6 \%$ (T 355/87) for A. minor, followed by $94 \cdot 0$ (Ac 7, F $119, \mathrm{~F} 141$ ) to $94.8 \%$ (A. hominis) for A. delphinicola.

In conclusion, equine actinobacilli tentatively classified as taxon 11 and within the species $A$. equuli all belong to the genuine actinobacilli according to the definition

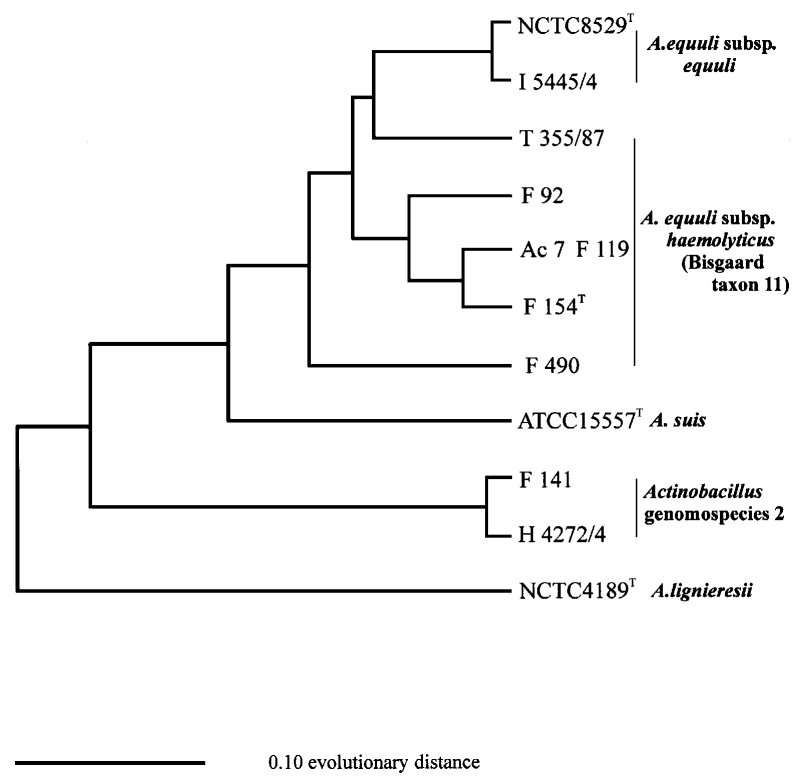

Fig. 2. Phylogenetic relationships between selected taxa associated with horses and genuine actinobacilli based on pairwise DNA-DNA hybridization experiments. The phylogram was constructed by the Fitch-Margoliash program with the 'contemporary tips' option on the basis of the complete DNAbinding matrix (available as supplementary material in IJSEM Online; http://ijs.sgmjournals.org/).

given above. It has to be emphasized that further investigation is necessary to obtain a strict definition of Actinobacillus, especially with respect to the classification of A. minor.

\section{DNA-DNA hybridization}

DNA binding of $98 \%$ was observed between $(+) \mathrm{L}-$ arabinose-positive and -negative strains of $A$. equuli, underlining that differences in production of acid from $(+)$ L-arabinose are taxonomically insignificant within this group. DNA-binding values between 78 and $100 \%$ were observed for strains belonging to taxon 11. The lowest DNA-binding value was observed between isolates from the Czech Republic and the Zimbabwe isolates, respectively representing biovars 2 and $1.16 \mathrm{~S}$ rRNA analysis showed one strain of taxon 11 to be closely related to the type strain of $A$. ureae. This relationship was investigated further by DNA-DNA hybridization. However, only $45 \%$ DNA binding was found between these strains. A full DNA-binding matrix is available as supplementary material in IJSEM Online (http://ijs.sgmjournals.org/).

The result of the phylogenetic analysis of DNA binding is shown in Fig. 2. Selected strains of all biovars of taxon 11 formed a monophyletic group at or above $78 \%$ DNA binding. The type strain of $A$. equuli and strain I 5445/4 were separated from strains of taxon 11 at $88 \%$ DNA binding. The type strain of $A$. suis branched more deeply (43-77\% DNA binding), with less than $77 \%$ DNA binding to the equine strains 
investigated, and so did Actinobacillus genomospecies 2 (Bisgaard taxon 9).

16S rRNA sequence comparison showed that the equine strains formed only weakly defined groups. One strain was found closely related to $A$. ureae, $A$. arthritidis and Actinobacillus genomospecies 2, while other strains formed a loose, comb-like structure (Fig. 1). The groups recognized by phylogenetic analysis of 16S rRNA sequences were not supported by DNADNA hybridization results, as this analysis grouped all strains of taxon 11 together (Fig. 2). This discrepancy is related to inappropriate resolution of $16 \mathrm{~S}$ rRNA sequence comparison at the species level for genuine actinobacilli, as demonstrated by the high 16S rRNA similarities observed between these strains. Except for A. pleuropneumoniae, $16 \mathrm{~S}$ rRNA sequences have only been available for type strains of species of genuine actinobacilli. Published sequences of A pleuropneumoniae show more than $99.7 \% \quad 16 \mathrm{~S}$ rRNA sequence similarity. Similarity of $98 \%$ between strains of $A$. equuli and taxon 11 resulted in polyphyletic groupings of this taxon and showed that phylogenetic analysis based on 16S rRNA sequence analysis is of little value for resolving species within the genuine actinobacilli. Since the aim of the present study was the resolution of equine actinobacilli, hybridizations were not performed to all actinobacilli; however, because $16 \mathrm{~S}$ rRNA analysis showed that a single strain of taxon 11 was closely related to the type strain of $A$. ureae, this relationship was investigated further by DNA-DNA hybridization and found to be only $45 \%$. Previous investigations have shown $75 \%$ DNA binding between A. ureae and A. suis and, at most, $66 \%$ to $A$. equuli (Escande et al., 1984; Mutters et al., 1986). A solution to the problem of the failure of $16 \mathrm{~S}$ rRNA phylogenetic analysis to resolve individual species might include sequences of other genes and the use of this information for phylogenetic analysis.

Low variation has also been reported for some species of Vibrio and lactobacilli (Wiik et al., 1995; Vandamme et al., 1996), and no definitive limits for the separation of species on the basis of 16S rRNA sequence variation can be drawn (Stackebrandt \& Goebel, 1994; Vandamme et al., 1996). A threshold of $70 \%$ DNA binding has been used to separate species of bacteria; however, thresholds may vary for different bacterial groups (Vandamme et al., 1996) and for different DNA hybridization methods (Grimont et al., 1980). For Mannheimia, a limit of $85 \%$ DNA binding was found (Angen et al., 1999; Mutters et al., 1989); however, it seems likely that a threshold for actinobacilli is slightly lower. Using $80 \%$ DNA binding as a threshold, A. equuli (including strains of taxon 11) can be separated from $A$. hominis $(73 \%)$ and $A$. suis (58-77\% DNA binding). The binding between the two strains classified as $A$. equuli was $98 \%$; however, strains classified as taxon 11 showed values between 78 and $100 \%$, while DNA-binding values between strains classified as $A$. equuli and taxon 11 varied between 78 and $88 \%$. The limit for separation of the two groups of
A. equuli will then be $78 \%$ DNA binding, corresponding to the level used for separation between species.

Previously published data on selected strains showed $83 \%$ DNA binding between $A$. equuli strain NCTC $8529^{\mathrm{T}}$ and strain $\mathrm{F} 154^{\mathrm{T}}$ of taxon 11 biovar 2 (Bisgaard et al., 1984). Using the recently developed micro-well method for DNA-DNA hybridization (Christensen et al., 2000), $84 \%$ DNA binding was found between the same strains. DNA binding of $62 \%$ was observed between biovar 2 of taxon $11\left(\mathrm{~F} 154^{\mathrm{T}}\right)$ and $A$. suis $\left(\mathrm{CCM} 5586^{\mathrm{T}}\right)$ by the spectrophotometric method (Bisgaard et al., 1984). The same strains showed $66 \%$ DNA binding by the micro-well method in the present study. Using the S1 nuclease-trichloroacetic acid method, Escande et al. (1984) found 80\% DNA binding between strains NCTC $8529^{\mathrm{T}}$ of $A$. equuli and CCM 5587 (= F 490) of Bisgaard taxon 11. According to the micro-well method, $78 \%$ DNA binding was observed between the same pair of strains. In conclusion, the results obtained by the micro-well DNADNA hybridization method were in agreement with results published previously and based on other methods.

Although Bisgaard taxon 11 did not form a monophyletic unit by rRNA sequence comparison, DNADNA hybridizations showed that these organisms form a subgroup of A. equuli. Equine strains previously classified as taxon $11, A$. suis or haemolytic variants of A. equuli (Bisgaard et al., 1984) seem to represent a group of opportunistic pathogens that have been associated with different disease conditions in foals and horses, including stillborn foetuses, metritis, mastitis, septicaemia, arthritis, endocarditis, meningitis, respiratory infections and inflamed wounds (Bisgaard, 1993). A. equuli, however, is an opportunistic pathogen of both horses and pigs, found in association with various clinical conditions, especially in young animals. The most prominent and usual syndrome associated with this organism in foals is an acute, highly fatal septicaemia of newborn foals (sleepy foal disease) that may become chronic (joint ill) with lesions of purulent nephritis and arthritis (Bisgaard, 1993).

Although DNA-binding data allowed the classification of Pasteurella multocida as three distinct species (Mutters et al., 1985), the authors resisted doing so from a clinical viewpoint and instead proposed the division of $P$. multocida into three subspecies, which was supposed to be more useful for epidemiological purposes. For the same reasons, it is suggested that $A$. equuli (Van Straten) Haupt 1934 be divided into two subspecies, Actinobacillus equuli subsp. equuli subsp. nov., representing non-haemolytic (CAMP-negative) strains and associated with sleepy foal disease/joint ill and having a reservoir in horses and pigs, and Actinobacillus equuli subsp. haemolyticus subsp. nov., representing haemolytic or weakly haemolytic but CAMP-positive strains and having a reservoir so far involving horses only. The CAMP reaction is a cohaemolytic reaction on a blood-agar plate previously 
affected by staphylococcal $\beta$-haemolysin (Christie et al., 1944).

\section{Description of Actinobacillus equuli subsp. equuli subsp. nov.}

Actinobacillus equuli subsp. equuli (e.qu.u'li. L. gen. n. equuli of a foal).

Under Rule 46 of the Bacteriological Code, the creation of Actinobacillus equuli subsp. haemolyticus automatically leads to the creation of a second subspecies, Actinobacillus equuli subsp. equuli subsp. nov. In addition to the phenotypic characters consistent for all members of the genus, reactions common to both subspecies of $A$. equuli are positive reactions for catalase, glycerol, $(+) \mathrm{D}$-xylose, $(+) \mathrm{D}$-galactose, lactose, maltose, $(+) \mathrm{D}-\mathrm{melibiose}$, trehalose, raffinose, dextrin and $\alpha$-galactosidase. The $\mathrm{G}+\mathrm{C}$ content of both subspecies ranges from 40.0 to $43.4 \mathrm{~mol} \%$, with genome sizes of 1.7-1.8 GDa (Bisgaard et al., 1984; Bohácek \& Mráz, 1967; Piechulla et al., 1985). The main characters used for differentiation of the two subspecies are haemolysis and the CAMP reaction; $A$. equuli subsp. equuli subsp. nov. is non-haemolytic and CAMP-negative. Considerable amounts of extracellular slime are often associated with this subspecies. In this study, strain I 5445/4 was allocated to $A$. equuli subsp. equuli. Isolated from horses and pigs. Strain NCTC $8529^{\mathrm{T}}\left(=\right.$ ATCC $\left.19392^{\mathrm{T}}\right)$ is the type strain.

\section{Description of Actinobacillus equuli subsp. haemolyticus subsp. nov.}

Actinobacillus equuli subsp. haemolyticus (hae.mo. ly'ti.cus. Gr. n. haima blood; Gr. adj. lytikos loosening, dissolving; N.L. adj. haemolyticus blood-dissolving).

Haemolytic and CAMP-positive. Reactions for the separation of $A$. equuli subsp. haemolyticus into biovars are shown in Table 2. Strains Ac 7, F 92, F 119, F 490 and $\mathrm{T} 355 / 87$, tentatively classified as Bisgaard taxon 11, are allocated to A. equuli subsp. haemolyticus. Strains have so far been isolated from horses only. Strain F $154^{\mathrm{T}} \quad\left(=\right.$ CCUG $19799^{\mathrm{T}}=$ NCTC $\left.13195^{\mathrm{T}}\right)$ is the type strain.

\section{ACKNOWLEDGEMENTS}

Sabina Misimovic, Gitte Frederiksen and Stina Holm are thanked for technical assistance. Dr Sten Ebbesen, Institute for Greek and Latin, University of Copenhagen, Denmark, is thanked for help with the Latin name. The study was financed by the Danish Agricultural and Veterinary Research Council, grant no. 9702797.

\section{REFERENCES}

Angen, Ø., Mutters, R., Caugant, D. A., Olsen, J. E. \& Bisgaard, M. (1999). Taxonomic relationships of the [Pasteurella] haemolytica complex as evaluated by DNA-DNA hybridizations and 16S rRNA sequencing with proposal of Mannheimia haemolytica gen. nov., comb. nov., Mannheimia granulomatis comb. nov., Mannheimia glucosida sp. nov., Mannheimia ruminalis sp. nov. and Mannheimia varigena sp. nov. Int J Syst Bacteriol 49, 67-86.

Ashhurst-Smith, C., Norton, R., Thoreau, W. \& Peel, M. M. (1998). Actinobacillus equuli septicemia: an unusual zoonotic infection. J Clin Microbiol 36, 2789-2790.

Bisgaard, M. (1993). Ecology and significance of Pasteurellaceae in animals. Zentbl Bakteriol 279, 7-26.

Bisgaard, M., Piechulla, K., Ying, Y.-T., Frederiksen, W. \& Mannheim, W. (1984). Prevalence of organisms described as Actinobacillus suis or haemolytic Actinobacillus equuli in the oral cavity of horses. Comparative investigations of strains obtained and porcine strains of $A$. suis sensu stricto. Acta Pathol Microbiol Immunol Scand Sect B 92, 291-298.

Bisgaard, M., Houghton, S. B., Mutters, R. \& Stenzel, A. (1991). Reclassification of German, British and Dutch isolates of so-called Pasteurella multocida obtained from pneumonic calf lungs. Vet Microbiol 26, 115-124.

Blackall, P. J., Bisgaard, M. \& McKenzie, R. A. (1997). Characterisation of Australian isolates of Actinobacillus capsulatus, Actinobacillus equuli, Pasteurella caballi and Bisgaard taxa 9 and 11. Aust Vet $J$ 75, 52-55.

Blackall, P. J., Christensen, J. P. \& Bisgaard, M. (1998). Diversity among isolates of Actinobacillus equuli and related organisms as revealed by ribotyping. Aust Vet J 76, 423-425.

Blackall, P. J., Angen, Ø., Fegan, N., Blackall, L., Mutters, R. \& Bisgaard, M. (2001). Characterisation of a novel Mannheimia sp. from Australian feedlot cattle. Aust Vet J 79, 634-639.

Bohácek, J. \& Mráz, O. (1967). Basengehalt der Desoxyribonukleinsäure bei den Arten Pasteurella haemolytica, Actinobacillus lignieresii und Actinobacillus equuli. Zentbl Bakteriol Parasitenkd Infektionskr Hyg Abt 1 Orig 202, 468-478.

Carman, M. G. \& Hodges, R. T. (1982). Actinobacillus suis infection of horses. $N Z$ Vet J 30, 82-84.

Christensen, H., Angen, Ø., Mutters, R., Olsen, J. E. \& Bisgaard, M. (2000). DNA-DNA hybridization determined in micro-wells using covalent attachment of DNA. Int J Syst Evol Microbiol 50, 1095-1102.

Christensen, H., Bisgaard, M., Angen, Ø. \& Olsen, J. E. (2002). Final classification of Bisgaard taxon 9 as Actinobacillus arthritidis sp. nov. and recognition of a novel genomospecies for equine strains of Actinobacillus lignieresii. Int J Syst Evol Microbiol 52, 1239-1246.

Christie, R., Atkins, N. E. \& Munch-Petersen, E. (1944). A note on a lytic phenomenon shown by group B streptococci. Aust J Exp Biol Med Sci 2, 197.

Dewhirst, F. E., Paster, B. J. \& Bright, P. L. (1989). Chromobacterium, Eikenella, Kingella, Neisseria, Simonsiella, and Vitreoscilla species comprise a major branch of the beta group Proteobacteria by $16 \mathrm{~S}$ ribosomal ribonucleic acid sequence comparison: transfer of Eikenella and Simonsiella to the family Neisseriaceae (emend.). Int J Syst Bacteriol 39, 258-266.

Dewhirst, F. E., Paster, B. J., Olsen, I. \& Fraser, G. J. (1993). Phylogeny of the Pasteurellaceae as determined by comparison of $16 \mathrm{~S}$ ribosomal ribonucleic acid sequences. Zentbl Bakteriol 279, 35-44.

Dibb, W. L., Digranes, A. \& Tønjum, S. (1981). Actinobacillus lignieresii infection after a horse bite. Br Med J 283, 583-584.

Escande, F., Grimont, F., Grimont, P. A. D. \& Bercovier, H. (1984). Deoxyribonucleic acid relatedness among strains of Actinobacillus spp. and Pasteurella ureae. Int J Syst Bacteriol 34, 309-315.

Felsenstein, J. (1981). Evolutionary trees from DNA sequences: a maximum likelihood approach. $J$ Mol Evol 17, 368-376.

Felsenstein, J. (1995). PHYLIP (Phylogeny Inference Package) version 3.5c. Seattle: Department of Genetics, University of Washington.

Foster, G., Ross, H. M., Malnick, H., Willems, A., Garcia, P., Reid, R. J. \& Collins, M. D. (1996). Actinobacillus delphinicola sp. nov., a new member of the family Pasteurellaceae Pohl (1979) 1981 isolated from sea mammals. Int J Syst Bacteriol 46, 648-652.

Foster, G., Ross, H. M., Patterson, I. A. P., Hutson, R. A. \& Collins, M. D. (1998). Actinobacillus scotiae sp. nov., a new member of the 
family Pasteurellaceae Pohl (1979) 1981 isolated from porpoises (Phocoena phocoena). Int J Syst Bacteriol 48, 929-933.

Grimont, P. A. D., Popoff, M. Y., Grimont, F., Coynault, C. \& Lemelin, M. (1980). Reproducibility and correlation study of three deoxyribonucleic acid hybridization procedures. Curr Microbiol 4, 325-330.

Guettler, M. V., Rumler, D. \& Jain, M. K. (1999). Actinobacillus succinogenes sp. nov., a novel succinic-acid-producing strain from the bovine rumen. Int $J$ Syst Bacteriol 49, 207-216.

Hedegaard, J., Okkels, H., Bruun, B., Kilian, M., Mortensen, K. K. \& Nørskov-Lauritsen, N. (2001). Phylogeny of the genus Haemophilus as determined by comparison of partial infB sequences. Microbiology 147, 2599-2609.

Jang, S. S., Biberstein, E. L. \& Hirsch, D. C. (1987). Actinobacillus suis-like organisms in horses. Am J Vet Res 48, 1036-1038.

Lane, D. (1991). 16S/23S rRNA sequencing. In Nucleic Acid Techniques in Bacterial Systematics, pp. 115-147. Edited by E. Stackebrandt $\&$ M. Goodfellow. New York: Wiley.

Leisner, J. J., Pot, B., Christensen, H., Rusul, G., Olsen, J. E., Wee, B. W., Muhamad, K. \& Ghazali, H. M. (1999). Identification of lactic acid bacteria from chili bo, a Malaysian food ingredient. Appl Environ Microbiol 65, 599-605.

Mannheim, W. (1984). Family III. Pasteurellaceae Pohl 1981a, $382^{\mathrm{VP}}$. In Bergey's Manual of Systematic Bacteriology, vol. 1, pp. 550-552. Edited by N. R. Krieg \& J. G. Holt. Baltimore: Williams \& Wilkins.

Mohan, K., Muvavarirwa, P. \& Pawandiwa, A. (1997). Strains of Actinobacillus spp. from diseases of animals and ostriches in Zimbabwe. Onderstepoort J Vet Res 64, 195-199.

Møller, K., Fussing, V., Grimont, P. A. D., Paster, B. J., Dewhirst, F. E. \& Kilian, M. (1996). Actinobacillus minor sp. nov., Actinobacillus porcinus sp. nov., and Actinobacillus indolicus sp. nov., three new V factor-dependent species from the respiratory tract of pigs. Int $J$ Syst Bacteriol 46, 951-956.

Mráz, O., Zakopal, J. \& Matoúseh, Z. (1968). The finding of a haemolytic variant of Actinobacillus equuli as the cause of septicaemia in a herd of breeding mares. Acta Univ Agric Brno 37, 263-275.

Mutters, R., Piechulla, K., Hinz, K.-H. \& Mannheim, W. (1985). Pasteurella avium (Hinz and Kunjara 1977) comb. nov. and Pasteurella volantium sp. nov. Int J Syst Bacteriol 35, 5-9.

Mutters, R., Pohl, S. \& Mannheim, W. (1986). Transfer of Pasteurella ureae Jones 1962 to the genus Actinobacillus Brumpt 1910: Actinobacillus ureae comb. nov. Int J Syst Bacteriol 36, 343-344.

Mutters, R., Mannheim, W. \& Bisgaard, M. (1989). Taxonomy of the group. In Pasteurella and Pasteurellosis, pp. 3-34. Edited by C. Adlam \& J. M. Rutter. London: Academic Press.
Olsen, G. J., Matsuda, H., Hagström, R. \& Overbeek, R. (1994). fastDNAmL: a tool for construction of phylogenetic trees of DNA sequences using maximum likelihood. Comput Appl Biosci 10, 41-48.

Paster, B. J. \& Dewhirst, F. E. (1988). Phylogeny of campylobacters, wolinellas, Bacteroides gracilis, and Bacteroides ureolyticus by $16 \mathrm{~S}$ ribosomal ribonucleic acid sequencing. Int J Syst Bacteriol 38, 56-62.

Peel, M. M., Hornidge, K. A., Luppino, M., Stacpoole, A. M. \& Weaver, R. E. (1991). Actinobacillus spp. and related bacteria in infected wounds of humans bitten by horses and sheep. J Clin Microbiol 29, 2535-2538.

Phillips, J. E. (1984). Genus III. Actinobacillus Brumpt 1910, $849^{\mathrm{AL}}$. In Bergey's Manual of Systematic Bacteriology, vol. 1, pp. 570-575. Edited by N. R. Krieg \& J. G. Holt. Baltimore: Williams \& Wilkins.

Piechulla, K., Bisgaard, M., Gerlach, H. \& Mannheim, W. (1985). Taxonomy of some recently described avian Pasteurella/Actinobacilluslike organisms as indicated by deoxyribonucleic acid relatedness. Avian Pathol 14, 281-311.

Samitz, E. M. \& Biberstein, E. L. (1991). Actinobacillus suis-like organisms and evidence of hemolytic strains of Actinobacillus lignieresii in horses. Am J Vet Res 52, 1245-1251.

Sneath, P. H. A. \& Stevens, M. (1990). Actinobacillus rossii sp. nov., Actinobacillus seminis sp. nov., nom. rev., Pasteurella bettii sp. nov., Pasteurella lymphangitidis sp. nov., Pasteurella mairi sp. nov., and Pasteurella trehalosi sp. nov. Int J Syst Bacteriol 40, 148-153.

Stackebrandt, E. \& Goebel, B. M. (1994). Taxonomic note: a place for DNA-DNA reassociation and $16 \mathrm{~S}$ rRNA sequence analysis in the present species definition in bacteriology. Int $J$ Syst Bacteriol 44, 846-849.

Sternberg, S. \& Brändström, B. (1999). Biochemical fingerprinting and ribotyping of isolates of Actinobacillus equuli from healthy and diseased horses. Vet Microbiol 66, 53-65.

Vandamme, P., Pot, B., Gillis, M., De Vos, P., Kersters, K. \& Swings, J. (1996). Polyphasic taxonomy, a consensus approach to bacterial systematics. Microbiol Rev 60, 407-438.

Vogel, B. F., Jørgensen, K., Christensen, H., Olsen, J. E. \& Gram, L. (1997). Differentiation of Shewanella putrefaciens and Shewanella alga on the basis of whole-cell protein profiles, ribotyping, phenotypic characterization, and 16S rRNA gene sequence analysis. Appl Environ Microbiol 63, 2189-2199.

Ward, C. L., Wood, J. L. N., Houghton, S. B., Mumford, J. A. \& Chanter, N. (1998). Actinobacillus and Pasteurella species isolated from horses with lower airway disease. Vet Rec 143, 277-279.

Wiik, R., Stackebrandt, E., Valle, O., Daae, F. L., Rødseth, O. M. \& Andersen, K. (1995). Classification of fish-pathogenic vibrios based on comparative 16S rRNA analysis. Int J Syst Bacteriol 45, 421-428. 